\title{
THE RELATIONSHIP BETWEEN MOTHER'S OCCUPATION, ADEQUACY LEVELS OF ENERGY AND PROTEIN WITH INFANT'S NUTRITIONAL STATUS
}

\author{
Dian Anita Nilawati ${ }^{1}$, Lailatul Muniroh ${ }^{1}$ \\ ${ }^{1}$ Department of Public Nutrition, \\ Faculty of Public Health, Airlangga University, Surabaya, Indonesia \\ Correspondence Address: Dian Anita Nilawati \\ Email: diannila441@gmail.com
}

\begin{abstract}
Infant is one of vulnerable groups that have nutritional problems. High prevalence of nutritional problems could affect nutritional status that become an important concern. The determining factor of nutritional status includes nutritional intake and maternal occupation. The purpose of this study was to determine the relationship between maternal occupation and nutritional intake, with nutritional status of infants aged 6-12 months. This study used cross-sectional design, with nutrional status of infants as dependent variable; intake of the food energy sufficiency level and protein sufficiency level. Subject was selected by simple random sampling technique. The interview was conducted on 88 mothers of infants aged 6-12 months, which used questionnaire, form food recall $2 \times 24$ hours (breastfeeding and complementary feeeding), and anthropometric measurements (W/L index). Data analyzed used Spearman-Rank test and Coefficient Contingency. The results of this study showed that most of the infants had normal nutritional status $(76,1 \%)$. Maternal occupation $(\mathrm{p}=0,025)$ had correlation with nutritional status. The food energy sufficiency level $(p=0,047)$ had correlation with nutritional status and protein sufficiency level $(p=0,016)$ had correlation with nutritional status. The conclusion of this study is infant who get the sufficiency level of energy and protein sufficiency level adequate has normal nutritional status. Wasting infant tend to have inadequate energy and protein intake. This study suggest mothers to give complementary feeding appropriately the quantity and according to the stage of giving food to infant.
\end{abstract}

Keywords: maternal occupation, nutritional status of infant, the sufficiency level of energy, protein sufficiency level

\begin{abstract}
ABSTRAK
Bayi merupakan salah satu kelompok yang rentan mengalami masalah gizi. Masih tingginya prevalensi masalah gizi yang dapat berdampak pada status gizi menjadi hal penting untuk diperhatikan. Faktor yang menjadi penyebab dari status gizi adalah pekerjaan ibu dan asupan gizi. Tujuan dari penelitian ini adalah untuk menganalisis hubungan antara pekerjaan ibu, tingkat kecukupan energi dan tingkat kecukupan protein dengan status gizi bayi umur 6-12 bulan. Penelitian dilaksanakan dengan rancangan cross sectional. Tehnik sampling menggunakan simple random sampling. Penelitian dengan wawancara dilakukan menggunakan kuesioner, form food recall $2 \times 24$ hours (ASI dan MP-ASI), dan pengukuran antropometri (BB/PB). Data diolah dengan uji analisis Spearman Rank dan Coefisien Contingensi. Hasil penelitian menunjukkan sebagian besar bayi mempunyai status gizi normal $(76,1 \%)$. Hasil uji statistik didapatkan adanya hubungan pekerjaan ibu $(p=0,025)$ dengan status gizi bayi, hubungan tingkat kecukupan energi $(p=0,047)$ dengan status gizi bayi dan tingkat kecukupan protein $(p=0,016)$ dengan status gizi bayi. Kesimpulan dari penelitian adalah bayi yang tingkat kecukupan energi dan tingkat kecukupan protein adekuat maka mempunyai status gizi normal. Tingkat kecukupan energi dan protein semakin inadekuat maka bayi cenderung akan berstatus gizi kurus. Penelitian ini merekomendasikan kepada ibu untuk memberikan MP-ASI secara tepat kuantitasnya dan sesuai tahapan dalam pemberian makanan ke bayi.
\end{abstract}

Kata Kunci: pekerjaan ibu, status gizi bayi, tingkat kecukupan energi, tingkat kecukupan protein

\section{INTRODUCTION}

A problem in achieving the Sustainable Development Goals (SDGs) is malnutrition. Nutrition problems in developing countries include underweight, stunting, and wasting. Data obtained from UNICEF (2014) show that Indonesia has $37 \%$ of children suffering from stunting, $12 \%$ suffering from wasting, and $12 \%$ being overweight. 
Failed nutrition may lead to infant mortality. Paying attention to children's growth is one way to overcome this problem. The pattern of infant feeding should be concerned as their brain growth reaches around $75 \%$. In the first 1,000 days of a child's life, exclusive breastfeeding for 6 months and providing quality and timely can also reduce the death rate of under two million by $6 \%$ (National Development Planning Agency., 2010).

In Indonesia, infants usually suffer from undernutrition and over nutrition. Excess or lack of nutrient intake in infants can affect the nutritional status and health status. Nutritional problems can be permanent and unrecoverable even though children meet their nutritional needs in the future (Adriani, 2012).

Nutritional status contributes to the quality of Human Resources (HR), especially in terms of intelligence, productivity, and creativity. Poor infant's nutritional status can inhibit physical, mental, and cognitive growth. Factors that cause nutritional problems in infants can be divided into two, namely direct and indirect factors. Direct factors are related to food intake and infections, while indirect factors are concerned about work, knowledge, care patterns, social condition, economic condition, health services, etc. (Adriani, 2012).

One of the indirect factors affecting infant's nutritional status is mother's occupation. Working mothers do not have enough time to pay attention to their infants' adequacy level of food intake. If they do, infants can effectively improve their nutritional status (Kusumawati, 2014).

Moreover, inadequate breastfeeding is one of the direct factors for nutritional problems in infants. The World Health Organization (WHO) and the United Nations International Children's Emergency Fund (UNICEF) have recommended that children get breastfed for at least 6 months and Insiani Early Breastfeeding. In addition to improving infants' health, breastfeeding can also prevent obesity. Belfield and Kelly (2010) explain that breastfeeding can increase the probability of healthy condition and prevent obesity in infants. Giving supplementary food too early results in insufficient quality nutrients because infants cannot get breastfeeding optimally.

Nutritious food is the main capital of growth for infants (Walyono, 2010). Supplementary food should be given when an infant is 6 months old. Providing balanced nutritious supplementary food supports optimal growth and development. If breastfeeding is insufficient or supplementary food given do not meet the nutritional needs of the body, infant will suffer from malnutrition (Kurniasih, et al.c, 2010). Insufficient nutritional intake that causes malnutrition ultimately increases infant morbidity and mortality rate (Dietz, 2008).

Infants are the most vulnerable to nutritional problems compared to other age groups. They need food with high calories, protein, various vitamins and minerals.

Infancy is a part of the first two years of life known as the golden age in which infants experience very rapid growth and development. Nutrition determines human health and well-being (Sari, 2010).

The 2013 Basic Health Research shows that $5.7 \%$ Indonesian toddlers suffer from malnutrition, and $13.9 \%$. Indonesian toddlers suffer from malnutrition. The prevalence of malnutrition and undernourisment in children increased from 2007 to 2013, while the prevalence of underweight in toddlers was $6.8 \%$. The prevalence of obesity in toddlers reached $11.9 \%$. East Java province is one of the provinces which has high nutritional problems as indicated by the prevalence of underweight and obesity issues in 2015 at $15.6 \%$ and $2.2 \%$, respectively (Surabaya District Health Office, 2015).

Surabaya city also has high prevalence of malnutrition. The prevalence of underweight and obesity in Surabaya city was $16.9 \%$ and $3.1 \%$, respectively. Data collected in the working area of the 
Tanjungsari Primary Healthcare Center in 2015 show according to Body Weight/Age index, $4.9 \%$. toddlers were underweight. While in Surabaya, $22.8 \%$ toddlers were underweight (Surabaya District Health Office, 2015). The high prevalence of underweight and obesity and other malnutrition can be influenced by various factors including adequacy levels of energy and protein. Overviewing the nutritional problems in infants, this study aimed to analyze the relationship between mother's employment, adequacy level of energy, and adequacy level of protein with the nutritional status of infants aged 6-12 months in the working area of Tanjungsari Primary Healthcare Center, Surabaya.

\section{METHODS}

This study used a cross-sectional research design, in which data were collected at the same time and place (Notoatmodjo, 2010). This research design was done by identifying mother's work and measuring adequacy levels of energy and protein that infants receivedTanjungsari Primary Healthcare Center. This study was conducted in the working area of Tanjungsari Primary Healthcare Center in Surabaya from October 2016 to February 2017.

The research population was mothers who had infants aged 6-12 months and lived in the working area of the Tanjungsari Primary Healthcare Center in Surabaya. The research sample was selected using a simple random sampling technique from the population that met the criteria. There were 88 mothers willing to beinvolved. Their infants should have no LBW history and no birth defects. The sampling frame was obtained from the baby cohort book Tanjungsari Primary Healthcare Centerprovided by the primary healthcare center.

Measurement of infant's nutrition status based on Body weight/body length used a digital scale and length board. The results of the measurements were then compared to those that followed the WHOMGRS standard. Data were collected through questionnaire-based interview and $2 \times 24$ hour food recall form instead. Nutritional intake was calculated from the volume, energy, and protein of breast milk. If infants drink breast milk for 15 minutes, they would get the volume as follows:

ASI

$$
=\frac{500 \mathrm{ml}}{\mathrm{X}}=\mathrm{y} \mathrm{ml}
$$

Breast milk energy $=$

$\underline{500 \mathrm{ml} / 100 \mathrm{ml} \times 67 \mathrm{Kkal}}=\mathrm{Z}$

$$
\mathrm{X}
$$

Breast milk protein $=$

$\frac{500 \mathrm{ml} / 100 \mathrm{ml} \times 1.2 \mathrm{~g}=\mathrm{t} \text { gram }}{\mathrm{X}}$

Information :

$\mathrm{X}=$ the highest frequencies during the study

Furthermore, the volume, energy, and protein in the first day and so forth were totaled and averaged. The average consumption of energy and protein of breast milk was summed with energy and protein intake of supplementary food. Then, the data of summed energy and protein intake were compared to the energy and protein adequacy standard. Data were analyzed and presented in the forms of frequency distribution, cross-tabulation, and percentages. To determine the relationship between mother's occupation and infant's nutritional status, this study performed a contingency coefficient test. Meanwhile, the Spearmen Rank test was performed to find the relationship between adequacy levels of energy and protein with infants' nutritional status. This study has passed the ethical clearance with No: 13KEPK.

\section{RESULTS}

\section{Respondents' Characteristics}

Respondents in this study were 88 mothers who had infants aged 6-12 months and who lived in the working area of 
Tanjungsari Primary Healthcare Center. Table 1 shows that most of the repsondents had female babies aged 12 months old. The rest had babied at least aged9 months old.

Table 1. Frequency Distribution of Infants' Characteristics in the Working Area of Tanjungsari Primary Healthcare Center, Surabaya, 2016.

\begin{tabular}{llcr}
\hline $\begin{array}{l}\text { Independent } \\
\text { Variable }\end{array}$ & Category & n & \% \\
\hline \multirow{4}{*}{ Age } & 6 months & 10 & 11.4 \\
\cline { 2 - 4 } & 7 months & 10 & 11.4 \\
\cline { 2 - 4 } & 8 months & 10 & 11.4 \\
\cline { 2 - 4 } & 9 months & 5 & 5.7 \\
\cline { 2 - 4 } & 10 months & 18 & 20.5 \\
\cline { 2 - 4 } & 11 months & 12 & 13.6 \\
\hline Gender & Male & 39 & 44.3 \\
\cline { 2 - 4 } & Female & 49 & 55.7 \\
\hline
\end{tabular}

Mothers' age was categorized into age groups of <20 years, 20-35 years, and $>35$ years. Table 2 shows that most of the mothers were in the age group of 20-35 years $(89.8 \%)$. These results indicate that they had been in early adulthood. The majority were 30 years old. This study categorized birth spacing into 2 groups: close ( $<24$ months) and enough birth spacing ( $\geq 24$ months or single/first child). Most of the mothers had spaced one birth to another $(98.9 \%)$; in other words, their infants had sufficient age difference. In terms of breastfeeding, most of the mosthers still breastfed infants during 6-12 months.

\section{Mother's occupation}

Figure 1 shows that $63.6 \%$ of the mothers did not work. In accordance with the results of the interview, they worked as private employees.

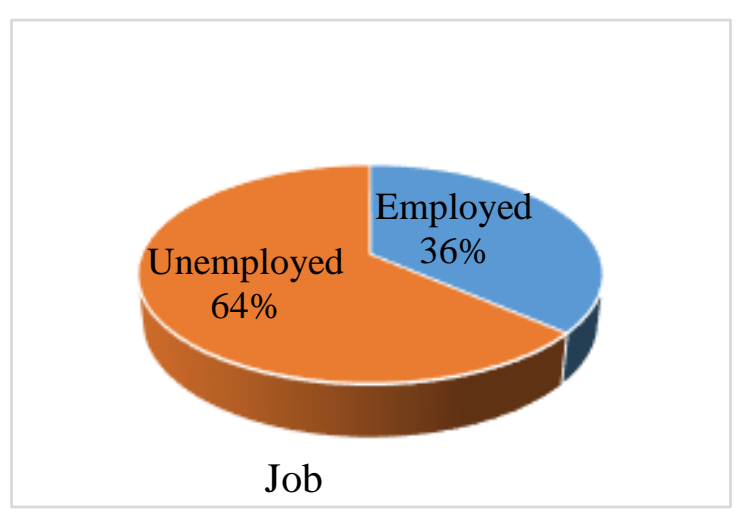

Figure 1. Frequency Distribution of Mothers' Characteristics by Occupation.

Table 2. Frequency Distribution of Mothers' Characteristics in the Working Area of the Tanjungsari Primary Healthcare Center,

\begin{tabular}{llcc}
\hline $\begin{array}{l}\text { Independent } \\
\text { Variable }\end{array}$ & Category & n & $\%$ \\
\hline Age & 20-35 & 79 & 83.3 \\
& Years & & \\
\cline { 2 - 4 } & $>35$ Years & 9 & 10.2 \\
\hline Birth Distance & Close & 1 & 1 \\
\cline { 2 - 4 } & Sufficient & 78 & 99 \\
\hline Infant feeding & Breast & 50 & 56.8 \\
& Milk & & \\
\cline { 2 - 4 } & No Breast & 38 & 43.2 \\
& Milk & & \\
\hline
\end{tabular}

Surabaya, 2016.

\section{Adequacy level of energy}

Adequacy level of energy was categorized into two types. The infants were considered to have adequate energy intake if the adequacy level of energy was at $\geq 77 \%$ RDA. While inadequate level of energy reached $<77 \%$ RDA. 
Table 3. Frequency Distribution of Adequacy Level of Energy in Infants Aged 6-12 Months in the Working Area of the Tanjungsari Primary Healthcare Center, Surabaya, 2016.

\begin{tabular}{lll}
\hline Nutritional status & $\mathbf{n}$ & $\mathbf{\%}$ \\
\hline Very thin & 0 & 0.0 \\
\hline Thin & 7 & 8.0 \\
\hline Normal & 67 & 76.1 \\
\hline Fat & 6 & 6.8 \\
\hline Very fat & 3 & 3.4 \\
\hline
\end{tabular}

Table 3 illustrates that the infants had adequate level of energy (69.3\%).

\section{Adequacy Level of Protein}

Adequacy level of protein also used the same categories. Infants were considered adequate protein if the adequacy level of protein reached $\geq 77 \%$ RDA. Contrastly, those with the adequacy level of protein at $<77 \%$ RDA would be considered to have inadequate protein. Based on Table 4, this study explains most infants had adequate levels of protein $(77.3 \%)$.
Table 4. Frequency Distribution of Adequacy Level of Protein in Infants Aged 6-12 Months in the Working Area of the Tanjungsari Primary Healthcare Center, Surabaya, 2016.

\begin{tabular}{lll}
\hline Nutritional status & n & \% \\
\hline Adequate & 61 & 69.3 \\
\hline Inadequate & 27 & 30.7 \\
\hline
\end{tabular}

\section{Infant's Nutritional Status}

Infants' nutritional status measurements were categorized into 5 groups: very thin, thin, normal, fat, and very fat.

Table 5. Distribution of Frequency of Nutritional Status in Infants Aged 6-12 Months based on Body Weight/Body Leght

\begin{tabular}{lll}
\hline Nutritional status & $\mathbf{n}$ & $\mathbf{\%}$ \\
\hline Adequate & 7 & 77.3 \\
\hline Inadequate & 67 & 22.7 \\
\hline
\end{tabular}

This study presents that most of the infants had normal nutritional status (76.1\%), but $8 \%$ of them were underweight

Table 6. The relationship between Adequacy Levels of Energy and Protein Adequacy Levels with Nutritional Status of Infants Aged 6-12-Months in the Working Area of the Tanjungsari Primary Healthcare Center in Surabaya in 2016.

\begin{tabular}{|c|c|c|c|c|c|c|c|c|c|c|c|}
\hline \multirow{3}{*}{ Variables } & \multirow{3}{*}{$\begin{array}{l}\text { Categorie } \\
\quad \mathrm{s}\end{array}$} & \multicolumn{10}{|c|}{ Nutritional status } \\
\hline & & \multicolumn{2}{|c|}{ Very thin } & \multicolumn{2}{|c|}{ Thin } & \multicolumn{2}{|c|}{ Normal } & \multicolumn{2}{|c|}{ Fat } & \multicolumn{2}{|c|}{ Very Fat } \\
\hline & & $\mathbf{n}$ & $\%$ & $\mathbf{n}$ & $\%$ & $\mathbf{n}$ & $\%$ & $\mathbf{n}$ & $\%$ & $\mathbf{n}$ & $\%$ \\
\hline \multirow{2}{*}{$\begin{array}{l}\text { Mother's } \\
\text { Accupation }\end{array}$} & Employed & 5 & 12.6 & 18 & 56.3 & 4 & 12.5 & 2 & 6.3 & 3 & 9.4 \\
\hline & $\begin{array}{l}\text { unemploy } \\
\text { ed }\end{array}$ & 2 & 3.6 & 49 & 87.5 & 2 & 3.6 & 1 & 1.8 & 2 & 3.6 \\
\hline \multirow{2}{*}{$\begin{array}{ll}\text { Adequacy } & \\
\text { Level } & \text { of } \\
\text { Energy } & \end{array}$} & Adequate & 2 & 3.3 & 47 & 77.0 & 5 & 8.2 & 3 & 4.9 & 4 & 6.6 \\
\hline & Inadequate & 5 & 18.5 & 20 & 74.1 & 1 & 3.7 & 0 & 0.0 & 1 & 3.7 \\
\hline \multirow{2}{*}{$\begin{array}{l}\text { Adequacy } \\
\text { Level of } \\
\text { Protein }\end{array}$} & Adequate & 3 & 4.4 & 52 & 76.5 & 6 & 8.8 & 3 & 4.4 & 4 & 5.9 \\
\hline & Inadequate & 4 & 20.0 & 15 & 75.0 & 0 & 0.0 & 0 & 0.0 & 1 & 5.0 \\
\hline
\end{tabular}


Table 7. The Relationship between Independent Variables and Nutritional Status of Infants Aged 6-12 Months in the Working Area of Tanjungsari Primary Healthcare Center, Surabaya in 2016.

\begin{tabular}{lccc}
\hline \multicolumn{1}{c}{ Variables } & $\mathbf{p}$ & Notes & $\mathbf{r}$ \\
\hline Mother's occupation & 0.025 & $\begin{array}{c}\text { There is a } \\
\text { relationship }\end{array}$ & 0.335 \\
\hline Adequacy level of energy & 0.016 & $\begin{array}{c}\text { There is a } \\
\text { relationship }\end{array}$ & 0.257 \\
\hline Adequacy level of protein & 0.020 & $\begin{array}{c}\text { There is a } \\
\text { relationship }\end{array}$ & 0.247 \\
\hline
\end{tabular}

Table 6 shows that infants with adequate energy levels had a normal nutritional status (77\%). Furthermore, those with adequate protein levels had a normal nutritional status as well $(76.5 \%)$. However, some babies had underweight status although they had adequate energy levels.

In Table 7, the analysis shows there was a weak relationship between adequacy level of energy and infant nutritional status $(\mathrm{p}=0.016 ; \mathrm{r}=0.257)$.

Moreover, adequacy level of proten had a weak relationship with infants' nutritional status $(\mathrm{p}=0.02 ; \mathrm{r}=0.247)$.

\section{DISCUSSION}

\section{Respondents' Characteristics}

Age is an indicator for determining individual's productivity. Older people compared to younger people have less productivity due to the less fit physical condition and health. Age will affect parental roles in providing nutrition to infants. It can be seen from this study where most of the mothers were in the age of 2035 years. According to Mubarak (2012), there will be physical and psychological changes in older ages. Psychological or mental aspects in older ages become more mature. The mothers had enough knowledge and experience about giving nutrition for their infants.

Too close births can interfere child's physical and mental growth. Mothers tend to not have much time to prepare food for babies at the same time, and maternalhealth condition was not fully fit. Too close births, as a result, affect mothers' psychological condition which can hinder breast milk production (Soetjiningsih., 2016).

The results indicate that almost all infants with normal nutritional status had adequate birth spacing (more than 24 months). The birth spacing is sufficient to help parents formulate the optimal care for their children, for instance providing nutritious food (Adriani, 2012).

Hasnain, and Sophie, 2010) and (Umeta, et al., 2003) further support this finding by stating that babies born more than 24 months after previous birth did not experience nutritional problems. Research conducted by Candra (2013) also finds that babies with birth spacing of more than two years were not at risk of nutritional problems because their parents took care of them optimally and monitored their nutrition intake.

Breast milk is a very important for infants because it provides infant's nutritional needs and contains immune substances that can enhance health. Breastfeeding for infants is highly recommended because it can support the early stages of infant growth.

The results show that most infants were breastfed. Similarly, research by Ratnaningsih, (2011) explains there was a relationship between the period of breastfeeding and nutritional status of 
infants aged 6-12 months in Demak regency. Giri, (2013) also discovers a relationship between exclusive breastfeeding with nutritional status of infants aged 6-24 months.

\section{The relationship between mother's occupation and infant's nutritional status}

Mother's occupation determines to which extent mothers pay attention to their infants' growth. Working mothers usually had little time to spendwith their infants, and thus they put less attention on their infant growth (Ariningsih, and Rachman, 2008).

The results of this study indicate that most of the mothers were unemployed. In fact, mother's occupation had a relationship with infant's nutritional status. This is in line with research conducted by Sulistyorini and Rahayu (2009), who find a relationship between mother's occupation and infant's nutritional status. In other words, unemployed mothers had infants with better nutritional status. Farhanah and Naleena, (2012), also further elaborates that the occupational status of mothers could play an important role in determining child feeding practices which can affect infant's health and nutritional status. It means unemployed mothers could feed children better according to the age of the baby. Little time spent with babies will affect parental role. Poor parental role, therefore, will affect nutrition intake for infants as babies still depend on their caregivers.

\section{The relationship between adequacy levels of energy and protein with infant's nutrition status}

Giving supplementary food too early can increase allergic reactions as babies' digestive tract is not perfect yet to process solid foods which result in an increased risk of infection and obesity (Barasi, 2007).

Good nutrition intake is inseparable from parental role in managing child feeding pattern. Breastmilk only gives babies minimum food intake until they are at the age of 6 months. When babies are older, they need more nutrients from supplementary food (MP-ASI). Baby's digestive system requires an adaptation process to solid food unless they will be prone to diarrhea due to imperfect digestion. So that breast milk must still be given as an immune substance (Nur and Marissa, 2014). if babies are ready to digest solid foods but not given supplementary food yet, they will delay the process of development and growth (Barasi, 2007).

The more adequate breastfeeding, the better the infant's nutritional status. Supplementary food only adds more nutrients as a baby gets older. Nutrious food is required to produce energy, protein, and all nutrients that fit the baby's needs. As infancy physical and mental growth occurs very quickly, intelligence and agility are more visible. Failing to meet the needs will affect poor nutritional status (Adriani, 2012).

The results show that most of the infants with adequate energy intake had normal nutritional status. In other words, adequacy level of energy had a relationship withinfant's nutritional status $(p=0.016)$. Futher, Meipita, (2009) discovers a relationship between adequacy level of energy produced from supplementary food with the nutritional status of infants aged 612 months.

Afriyani's research (2016) also finds a significant relationship between nutrient intake and wasting cases at Talang Betutu Primary Healthcare Center in Palembang city. Wasting is a type of malnutrition in which infant's weight does not go right with the height or the $\mathrm{z}$ score of more than -2SD. Wasting in children can disrupt child growth and even lead to death. A child who gets enough nutrient intake is less likely to experience wasting or nutritional problems. Ernawati's research (2009) finds a relationship between adequacy level of energy and child's nutritional status as well.

The low energy intake may be due to several factors including the frequency of 
feeding and amount of foods, appetite, and infectious diseases (Astari, 2005). It is also important to pay attention to the process of food preparation and food hygiene (Soetjiningsih., 2016).

Research by Meilyasari and Isnawati, (2014) in Purwokerto shows that low energy and protein intake in infants was related to nutritional problems. Lack of nutrition intake, especially energy and protein in the long term, can cause baby's weight loss, susceptibility to infection, and growth and development problems (Dewey and Mayers, 2011).

This finding is relevant to Ningrum's study (2004), which find that good complementary feeding that fulfills babies' nutrient needs could reduce the occurrence of less protein energy in infants in the Muktiharjo Kidul sub-district, Pedurungan district, Semarang city. Another previous study conducted by Setiani (2012) shows a relationship between the risk of infectious diseases and the nutritional status of infants aged 6-12 months. Infants who had an infectious disease were twice more likely to have poor nutritional status as the immune system did not defend children from infectious diseases.

Feeding style for children should be concerned to meet the nutrition intake, such as protein. Infants aged 6-12 months need not only breast milk but also supplementary food to fulfill higher nutrition needs (Istiany, A., 2014).

Like energy, protein with the right proportion is necessary in early growth. Insufficent nutrition intake will cause infection and even growth disorders (Fitriana, 2013). Therefore, supplementary foods in addition to breast milk could provide protein intake for infants older than 6 months (Darmayanti, 2014).

\section{CONCLUSION}

In summary, most of the mothers in the working area of Tanjungsari Primary Healthcare Center in Surabaya were aged between 20-35 years and unemployed.
Most of them breastfed their babies and had sufficient birth spacing.

Their infants mostly had adequate energy and protein levels. This also was dealing with their nutritional status which this study finds normal.

Mother's occupation had a relationship with infants' nutritional status. In the same way, adequacy levels of energy and protein were related to infants' nutritional status.

Mothers should give supplementary foos appropriate for infants' age to support optimal growth and normal nutritional status. It is recommended that working mothers pay more attention to provide nutritional supplementary food for their babies

\section{REFERENCE}

Adriani, M., 2012. Peranan Gizi dalam Siklus Kehidupan. Jakarta: Kencana.

Afriyani, R., 2016. Faktor - Faktor Yang Mempengaruhi Kejadian Wasting Pada Balita Usia 1-5 Tahun Di Puskesmas Talang Betutu Kota Palembang. Jurnal Kesehatan., 7(1, April), pp.66-72. https://doi.org/10.26630/jk.v7i1.120

Ariningsih, E., and Rachman, H.P.S., 2008. Strategi Peningkatan Ketahanan Pangan Rumah Tangga Rawan Pangan. Analisis Kebijakan Pertanian., 6(3), pp.239-255.

Astari, L.D.A., Dwiriani, C.M., 2005. Hubungan Karakteristik Keluarga, Pola Pengasuhan dan Kejadian Stunting Anak Usia 6-12 Bulan. Media Gizi dan Keluarga., 29(2), pp.40-46.

National Development Planning Agency., 2010. Periode Emas pada 1000 Hari Pertama Kehidupan.

Barasi, M.E., 2007. Ilmu Gizi. Jakarta: Erlangga.

Belfield, C.R., Kelly, I.R., 2010. The Benefits of Breastfeeding Accros The Early Years of Childhood. 
Journal of Human Capital., 6(3), pp.251-277.

https://doi.org/10.1086/667415

Candra, A., 2013. Hubungan Underlying Factors Dengan Kejadian Stunting pada Anak 1-2 Tahun. Journal of Nutrition and Health., 1(1).

Darmayanti, F., 2014. Variasi MP ASI Harian. Jakarta : Notebook.

Dewey, K.G,. Mayers, D.R., 2011. Early Child Growth: How Do Nutition and Infection Interact. Blacwell Publishing Ltd Maternal an child Nutrition., (Suppl.3), pp.129-142. https://doi.org/10.1111/j.17408709.2011.00357.x

Dietz., 2008. Breastfeeding May Help Prevent Childhood Overweight. JAMA, 2000(285), pp.2506-7. https://doi.org/10.1001/jama.285.19. $\underline{2506}$

Surabaya District Health Office., 2015. Data Laporan PSG Kota Surabaya Tahun 2015.

Ernawati, A., 2009. Hubungan Faktor Sosial Ekonomi, Hygiene Sanitasi Lingkungan, Tingkat Konsumsi dan Infeksi Dengan Status Gizi Anak Usia 2-5 Tahun Di Kabupaten Semarang. Thesis. Universitas Diponegoro.

Farhanah S., and Naleena, D., 2012. The Association of Maternal Employment Status on Nutritional Status among Children in Selected Kindergartens in Selangor, Malaysia. Asian Journal of Clinical Nutrition, 4, pp.53-66. https://doi.org/10.3923/ajcn.2012.53. $\underline{66}$

Fitriana., 2013. Dampak Usia Pertama Pemberian Makanan Pendamping ASI Terhadap Status Gizi Bayi Usia 8-12 Bulan Di Kecamatan Seberang Ulu I Palembang. Sari Pediatri., 15(4 December), pp.249-253. https://doi.org/10.14238/sp15.4.2013 $.249-53$

Giri, M.K.W., 2013. Hubungan Pengetahuan Ibu dan Sikap Ibu tentang Pemberian ASI Eksklusif dengan Status Gizi Balita Usia 6-24 Bulan. Jurnal Magister Kedokteran Keluarga., 1(1), pp.24-37.

Hasnain, S., and Sophie, R., 2010. Prevalence and Risk Factors for Stunting Among Children Under 5 Years. Journal Pak Med Assue., 60(1), pp.41-44.

Istiany, A., R., 2014. Gizi Terapan. Bandung : Remaja Rosidakarya.

Kurniasih, D., Hilmansyah, H., Astuti, M.P., \& Imam, S., 2010. Sehat dan Bugar Berkat Gizi Seimbang. Jakarta : Penerbitan Sarana Bobo.

Kusumawati, D., 2014. Hubungan Pekerjaan, Pendidikan dan Pengetahuan Ibu tentang Makanan Pendamping ASI dengan Status Gizi Balita Usia 7-24 Bulan. Skripsi. Universitas Muhammadiyah Surakarta.

Meilyasari, F., dan Isnawati, M., 2014. Faktor Risiko kejadian Stunting pada Balita Usia 12 Bulan di Desa Purwokerto Kecamatan Patebon Kabupaten Kendal. Journal of Nutrition College., 3(2), pp.16-25. https://doi.org/10.14710/inc.v3i2.543 $\underline{7}$

Meipita, T., 2009. Hubungan Tingkat Pengetahuan Ibu, Pola Pemberian MP-ASI dengan Status Gizi Pada Bayi Usia 6-12 Bulan. Skripsi. Universitas Diponegoro.

Mubarak, W., 2012. Ilmu Kesehatan Masyarakat Konsep dan Aplikasi dalam Kebidanan. Jakarta: Salemba Medika.

Ningrum, I.A., 2004. Faktor-Faktor Yang Berhubungan Dengan Status Gizi Di Kelurahan Koto Karang Kecamatan teluk Belitung Barat Bandar Lampung. Skripsi. Univeristas Malahayati.

Nur, A., Marissa, N., 2014. Riwayat Pemberian Air Susu Ibu dengan Penyakit Infeksi pada Balita. Jurnal Kesehatan Masyarakat Nasional., $9(2 \quad$ November). https://doi.org/10.21109/kesmas.v9i2 .$\underline{.510}$ 
Ratnaningsih, E., 2011. Hubungan Pemberian ASI Eksklusif dan MP ASI Terhadap Status Gizi Bayi 6-12 Bulan. Jurnal Kebidanan Panti Wikasa., 2(1 October).

Sari, M., 2010. Higher Household Expenditure on Animal Source and Nongrain Foods Lowers the Risk of Stunting among Children 0-59 Months Old in Indonesia. J. Nutr., 140(1), pp.195S-200S. https://doi.org/10.3945/jn.109.11085 $\underline{8}$

Setiani, D., 2012. Faktor-Faktor Yang Berhubungan Dengan Status Gizi Bayi Usia 6-12 Bulan Di Posyandu Kelurahan "B" Kota Surakarta. Skripsi. STIK SINT Carolus.

Soetjiningsih., 2016. Tumbuh Kembang Anak. Jakarta : EGC.
Sulistyorini, E., and Rahayu, T., 2009. Hubungan Pekerjaan Ibu Balita Terhadap Status Gizi Balita Di Posyandu Prima Sejahtera Desa Pandean Kecamatan Ngemplak Kabupaten Boyolali. Jurnal Kebidanan Indonesia., 1(2 July).

Umeta, M., West, C.E., Verhoef, H., and Hautvast, J.G.A.J., 2003. Factors Associated with Stunting in Infants Ageed 5-11 Months in the DodotaSire District Rural Ethiopia. Journal of Nutrition., (133), pp.1064-1069. https://doi.org/10.1093/jn/133.4.1064

Walyono., 2010. Gizi Reproduksi. Yogyakarta : Pustaka Rihama. 